\title{
The Sūras of the Quran
}

The sūra names and numbers:

\begin{tabular}{|c|c|c|c|c|c|}
\hline al-Fātiḥa & الفاتحة & 001 & Luqmān & لقمان & 031 \\
\hline al-Baqara & البقرة & 002 & al-Sajda & السجدة & 032 \\
\hline 'Āl 'Imrān & آل عمران & 003 & al-'Aḥāāb & الأحزاب & 033 \\
\hline al-Nisā' & النساء & 004 & Saba' & سباً & 034 \\
\hline al-Mā’ida & المائدة & 005 & Fāṭir & فاطر & 035 \\
\hline al-'An'ām & الأنعام & 006 & Yasin & يس & 036 \\
\hline al-'A'rāf & & 007 & al-Ṣāffāt & الصافات & 037 \\
\hline al-'Anfāl & الأنفال & 008 & Șāḍ & ص & 038 \\
\hline al-Tawba & التوبة & 009 & al-Zumar & الزمر & 039 \\
\hline Yūnus & يونس & 010 & Ġāfir & غافر & 040 \\
\hline Hūd & هود & 011 & Fusșilat & فصلت & 041 \\
\hline Yūsuf & يوسف & 012 & al-Šsurā & الشورى & 042 \\
\hline al-Ra'd & الرعد & 013 & al-Zuhruf & الزخرف & 043 \\
\hline 'Ibrāhīm & إبراهيم & 014 & al-Duhān & الدخان & 044 \\
\hline al-Hijr & الحجر & 015 & al-Jātiya & الجاثية & 045 \\
\hline al-Naḥl & النحل & 016 & al-'Ahquāf & الأحقاف & 046 \\
\hline al-'Isrā' & الإسراء & 017 & Muḥammad & محمد & 047 \\
\hline al-Kahf & الكهف & 018 & al-Fath & الفتح & 048 \\
\hline Maryam & مريم & 019 & al-Ḥujurāt & الحجرات & 049 \\
\hline Ṭaha & طه & 020 & Qāf & ق & 050 \\
\hline al-'Anbiyā' & الأنبياء & 021 & al-D̄āriyāt & الذاريات & 051 \\
\hline al-Hajj & الحج & 022 & al-Ṭūr & الطور & 052 \\
\hline al-Mu'minūn & المؤمنون & 023 & al-Najm & النجم & 053 \\
\hline al-Nūr & النور & 024 & al-Qamar & القمر & 054 \\
\hline al-Furqān & الفرقان & 025 & al-Raḥmān & الرحمن. & 055 \\
\hline al-Š́u'arā' & الشعراء & 026 & al-Wāqi'a & الواقعة & 056 \\
\hline al-Naml & النمل & 027 & al-Hadīd & الحديد & 057 \\
\hline al-Qașaṣ & القصص & 028 & al-Mujādila & المجادلة & 058 \\
\hline al-'Ankabūt & العنكبوت & 029 & al-Ḥašr & الحشر & 059 \\
\hline al-Rūm & الروم & 030 & al-Mumtahana & الممتحنة & 060 \\
\hline
\end{tabular}




\begin{tabular}{|c|c|c|c|c|c|}
\hline al-Ṣaff & الصف & 061 & al-Ġāšiya & الغاشية & 088 \\
\hline al-Jumu'a & الجمعة & 062 & al-Fajr & الفجر & 089 \\
\hline al-Munāfiqūn & المنافقون & 063 & al-Balad & البلد & 090 \\
\hline al-Taḡābun & & 064 & al-Šams & الشمس & 091 \\
\hline al-Ṭalāq & الطلاق & 065 & al-Layl & & 092 \\
\hline al-Tahrīm & التحريم & 066 & al-Ḍuhāà & & 093 \\
\hline al-Mulk & الملك & 067 & al-ŠSarh & & 094 \\
\hline al-Qalam & & 068 & al-Tīn & التين & 095 \\
\hline al-Ḥ̄quqa & الحاقة & 069 & al-'Alaq & العلق & 096 \\
\hline al-Ma'ārij & & 070 & al-Qadr & القدر & 097 \\
\hline Nūḥ & & 071 & al-Bayyina & البينة & 098 \\
\hline al-Jinn & & 072 & al-Zalzala & الزلزلة & 099 \\
\hline al-Muzzammil & & 073 & al-'Ādiyāt & العاديات & 100 \\
\hline al-Muddattir & & 074 & al-Qārica & القارعة & 101 \\
\hline al-Qiyāma & & 075 & al-Takātur & التكاثر & 102 \\
\hline al-'Insān & الإنسان & 076 & al-'Aṣr & العصر & 103 \\
\hline al-Mursalāt & رسلات & 077 & al-Humaza & الهمزة & 104 \\
\hline al-Naba’ & & 078 & al-Fīl & & 105 \\
\hline al-Nāzi'āt & النازعات & 079 & Qurayš & قريش & 10 \\
\hline 'Abasa & & 080 & al-Māēun & الماعون & 107 \\
\hline al-Takwīr & & 081 & al-Kawtar & الكوثر & 108 \\
\hline al-’Infițār & الإنفطار & 082 & al-Kāfirūn & الكافرون & 109 \\
\hline al-Muṭaffifin & المطففين & 083 & al-Naṣr & النصر & 110 \\
\hline al-’Inšiqāq & الإنشقاق & 084 & al-Masad & المسد & 111 \\
\hline al-Burūj & البروج & 085 & al-'Ihlāṣ & & 11 \\
\hline al-Ṭāriq & الطارق & 086 & al-Falaq & الفلق & 113 \\
\hline al-'A'lā & على & 087 & al-Nās & الناس & 11 \\
\hline
\end{tabular}

In this book, The Quran is referenced according to the sūra and 'āya numbers separated by a colon.

For example:

001:001 refers to sūra 1, al-Fātiḥa, and 'āya 1;

015:045 refers to sūra 15, al-Hijr, and 'āya 45. 